OPEN ACCESS

Edited by:

Jake Bailey,

University of Minnesota, USA

Reviewed by:

Brandi Kiel Reese,

Texas A\&M University-Corpus Christi,

USA

Arthur J. Spivack University of Rhode Island, USA

*Correspondence:

Stefan Braun

stefan.braun@bios.au.dk

Specialty section:

This article was submitted to

Extreme Microbiology,

a section of the journal

Frontiers in Microbiology

Received: 09 June 2016 Accepted: 19 August 2016

Published: 31 August 2016

Citation:

Braun S, Morono Y, Littmann S,

Kuypers M, Aslan H, Dong M, Jørgensen $B B$ and Lomstein $B A$ (2016) Size and Carbon Content of

Sub-seafloor Microbial Cells at Landsort Deep, Baltic Sea.

Front. Microbiol. 7:1375

doi: 10.3389/fmicb.2016.01375

\title{
Size and Carbon Content of Sub-seafloor Microbial Cells at Landsort Deep, Baltic Sea
}

\section{Stefan Braun ${ }^{1 *}$, Yuki Morono ${ }^{2}$, Sten Littmann ${ }^{3}$, Marcel Kuypers ${ }^{3}$, Hüsnü Aslan ${ }^{4}$ Mingdong Dong ${ }^{4}$, Bo B. Jørgensen ${ }^{1}$ and Bente Aa. Lomstein ${ }^{1,5}$}

${ }^{1}$ Center for Geomicrobiology, Department of Bioscience, Aarhus University, Aarhus, Denmark, ${ }^{2}$ Geomicrobiology Group, Kochi Institute for Core Sample Research, Japan Agency for Marine-Earth Science and Technology, Kochi, Japan, ${ }^{3}$ Biogeochemistry Group, Max Planck Institute for Marine Microbiology, Bremen, Germany, ${ }^{4}$ Interdisciplinary Nanoscience Center, Aarhus University, Aarhus, Denmark, ${ }^{5}$ Section for Microbiology, Department of Bioscience, Aarhus University, Aarhus, Denmark

The discovery of a microbial ecosystem in ocean sediments has evoked interest in life under extreme energy limitation and its role in global element cycling. However, fundamental parameters such as the size and the amount of biomass of sub-seafloor microbial cells are poorly constrained. Here we determined the volume and the carbon content of microbial cells from a marine sediment drill core retrieved by the Integrated Ocean Drilling Program (IODP), Expedition 347, at Landsort Deep, Baltic Sea. To determine their shape and volume, cells were separated from the sediment matrix by multi-layer density centrifugation and visualized via epifluorescence microscopy (FM) and scanning electron microscopy (SEM). Total cell-carbon was calculated from amino acid-carbon, which was analyzed by high-performance liquid chromatography (HPLC) after cells had been purified by fluorescence-activated cell sorting (FACS). The majority of microbial cells in the sediment have coccoid or slightly elongated morphology. From the sediment surface to the deepest investigated sample ( $\sim 60 \mathrm{~m}$ below the seafloor), the cell volume of both coccoid and elongated cells decreased by an order of magnitude from $\sim 0.05$ to $0.005 \mu \mathrm{m}^{3}$. The cell-specific carbon content was $19-31 \mathrm{fg} \mathrm{C} \mathrm{cell}^{-1}$, which is at the lower end of previous estimates that were used for global estimates of microbial biomass. The cell-specific carbon density increased with sediment depth from about 200 to $1000 \mathrm{fg} \mathrm{C} \mu \mathrm{m}^{-3}$, suggesting that cells decrease their water content and grow small cell sizes as adaptation to the long-term subsistence at very low energy availability in the deep biosphere. We present for the first time depth-related data on the cell volume and carbon content of sedimentary microbial cells buried down to $60 \mathrm{~m}$ below the seafloor. Our data enable estimates of volume- and biomass-specific cellular rates of energy metabolism in the deep biosphere and will improve global estimates of microbial biomass.

Keywords: cell volume, carbon content, carbon density, cell extraction, FACS, IODP, Expedition 347, deep biosphere 


\section{INTRODUCTION}

The correct determination of bacterial cell size and biomass is critical for understanding many aspects of microbial ecology. For pure cultures and natural ecosystems on Earth's surface, both parameters have been determined for different levels of nutrient availability (e.g., Bratbak, 1985; Kogure and Koike, 1987; Simon and Azam, 1989; Fagerbakke et al., 1996; Troussellier et al., 1997; Fukuda et al., 1998; Romanova and Sazhin, 2010; Lever et al., 2015). However, little is known about size and biomass of cells in Earth's energy-limited subsurface, such as the extensive marine sediment.

The marine deep biosphere is cut off from surface energy supplies over geologic time scales. Microbes have to efficiently use the limited chemical potential energy in the sediment for producing ATP and synthesizing new biomass. Our knowledge of how microbial communities adapt to long-term subsistence at very low energy availability in the deep seabed remains fragmentary (Lever et al., 2015). Measuring cell size and biomass may help understand whether subsurface microorganisms physically adapt to the harsh conditions faced during burial. In addition, both parameters are important for estimating the significance of deep microbial communities in the global carbon cycle.

Bacterial cell size and biomass in the deep biosphere are poorly constrained possibly because the complex sediment matrix interferes with the analysis of whole cells and sub-cellular compounds. For accurate measurements of cell volume and cellular organic carbon, cells must first be separated from mineral grains and detrital organic particles, which is extremely difficult and time-consuming (Kallmeyer et al., 2008; Morono et al., 2013). Consequently, there is hardly any data on the size and cellular carbon content of cells in the deep biosphere.

Estimates of the total amount of microbial biomass (i.e., cellular organic carbon) in the seabed range from 4 to $300 \mathrm{Pg}$ C (Parkes et al., 1994; Whitman et al., 1998; Lipp et al., 2008; Kallmeyer et al., 2012). However, these estimates were not based on direct measurements of the carbon content of sub-seafloor microbial cells. Instead, they were based on mean cellular carbon contents that were deduced either from mean literature values (Parkes et al., 1994), cell dry weight (Whitman et al., 1998), sedimentary lipid biomarker concentrations (Lipp et al., 2008), or cell volumes (Kallmeyer et al., 2012). While the cell volumes and the lipid concentrations were quantified from actual subseafloor samples, the data for the dry weight consisted of one single data point obtained from a terrestrial aquifer (Balkwill et al., 1988). These parameters were then converted into cellular carbon contents using relationships determined for pure cultures or planktonic bacteria from water samples (e.g., Norland et al., 1987; Balkwill et al., 1988; Simon and Azam, 1989).

In this study, we quantified the cell volume and amino acidcarbon content of cells from a sediment drill core retrieved during IODP Expedition 347 in October 2013 at Landsort Deep, Baltic Sea (Expedition 347 Scientists, 2014). The drilling site was situated in the central part of the Landsort Deep, which is the deepest sub-basin ( $437 \mathrm{~m}$ water depth) in the Baltic Sea Basin. It contains a thick and continuous record of the last $\sim 14,000$ years, including the transition from Holocene, organic-rich clay to glacial, low-organic clay (Andrén et al., 2015). It is characterized by high sedimentation rates $(100-500 \mathrm{~cm}$ $\mathrm{kyr}^{-1}$ ), high concentrations of total organic carbon (TOC), and extremely high microbial abundance (up to $10^{10} \mathrm{cells}^{-3}$ ) in the organic-rich Holocene deposits (Andrén et al., 2015).

Cell sizes were determined by epifluorescence microscopy (FM) and scanning electron microscopy (SEM) after cells had been separated from the sediment matrix by multi-layer density centrifugation (Morono et al., 2013). Because of the relatively weak relationship between cell volume and carbon content (Romanova and Sazhin, 2010), the latter was independently estimated in seven samples that were purified by fluorescenceactivated cell sorting (Morono et al., 2013; Braun et al., 2016). To correct the FM-based cell sizes for the fluorescence halo-effect (when aureoles appear around the cell), we used correction factors obtained from volume measurements of cultured Escherichia coli and Micrococcus luteus cells by FM and atomic force microscopy (AFM). The cultured cells were also used to test whether the filtration of cells onto membrane filters affects the cell volume. Furthermore, literature values were used to correct for shrinkage due to cell fixation and critical point drying. Finally, the cell-specific carbon content was determined from direct measurements of cellular amino acids and by assuming that these contain $\sim 55 \%$ of total cell carbon (Ingraham et al., 1983).

Given the large extent of marine sediment on Earth, assessing the size and carbon content of sub-seafloor microbial cells will improve global estimates of microbial biomass and carbon turnover.

\section{MATERIALS AND METHODS}

\section{Samples}

A $120-\mathrm{m}$ long sediment core was taken by piston core drilling during IODP Leg 347 at Landsort Deep (58 $37.34 \mathrm{~N}, 18^{\circ} 15.25$ E; Site 63, Hole E) at $437 \mathrm{~m}$ water depth (Andrén et al., 2015). Perfluorocarbon (PFC) tracer was used while drilling to evaluate potential contamination of microbiology samples with cells from the drilling fluid. The average contamination level corresponded to the potential introduction of $10-100$ cells $\mathrm{cm}^{-3}$ of sediment (Andrén et al., 2015). In comparison to the in-situ cell abundance of $10^{8}-10^{10}$ cells $\mathrm{cm}^{-3}$, this was still less than a millionth of the indigenous community.

Sediment for cell extraction $\left(\sim 5 \mathrm{~cm}^{3}\right)$ was sub-sampled from whole-round core sections with sterile cut-off syringes and stored at $-80^{\circ} \mathrm{C}$ until further processing. For method development, we also used three surface sediment samples taken with a Rumohr corer during Expedition SA13 on the continental shelf in the Labrador Sea $\left(64^{\circ} 26.74 \mathrm{~N}, 52^{\circ} 47.65 \mathrm{~W}\right)$ at a water depth of $498 \mathrm{~m}$ in August 2013. Those three samples were placed in sealed airtight plastic bags along with an oxygen consuming pack (AnaeroGen, Oxoid, Roskilde Denmark) and stored anoxically at $4^{\circ} \mathrm{C}$ to keep cells intact. Cultures of E. coli (DSM 498) and M. luteus (DSM 20030) were grown in nutrient broth medium at $37^{\circ} \mathrm{C}$ and harvested in late exponential phase. Cultured cells were 
then fixed in paraformaldehyde (PFA, $2 \%$ final concentration) for $6 \mathrm{~h}$ at $4^{\circ} \mathrm{C}$, then washed $3 \times$ in phosphate-buffered saline (PBS), resuspended in PBS:ethanol 1:1, and stored at $-20^{\circ} \mathrm{C}$.

\section{Cell Separation}

All materials and reagents were filter-sterilized $(0.2 \mu \mathrm{m}$ pore size) and/or autoclaved before use. To separate intact microbial cells from the sediment matrix, we performed density gradient centrifugation on slurried sediment. Sediment $\left(0.5 \mathrm{~cm}^{3}\right)$ was fixed in PFA (2\% final concentration) for $6 \mathrm{~h}$ at $4^{\circ} \mathrm{C}$, then washed $3 \times$ in PBS and resuspended in PBS:ethanol 1:1 in $15-\mathrm{mL}$ Falcon tubes and stored at $-20^{\circ} \mathrm{C}$. Cell extraction was then performed based on the protocol of Morono et al. (2013). Fixed sediment slurries were centrifuged at $5000 \times$ $\mathrm{g}$ for $5 \mathrm{~min}$, after which the supernatant was discarded. The pelleted sediment was resuspended in $1.5 \mathrm{~mL}$ Milli-Q water that included $0.2 \mathrm{~mL}$ methanol and $0.2 \mathrm{~mL}$ detergent mix (consisting of $100 \mathrm{mM}$ EDTA, $100 \mathrm{mM}$ sodium pyrophosphate decahydrate, and 1\% v:v Tween 80). Samples were then shaken for $60 \mathrm{~min}$ at $750 \mathrm{rpm}$. After shaking, the samples were sonicated for $3 \times 15 \mathrm{~s}$ using an ultrasonic probe $(14 \mathrm{~W})$. To establish a density gradient, three layers of Nycodenz (30\%, 50\%, 80\% w:v; $2 \mathrm{~mL}$ each layer; Nycodenz from AXISSHIELD PoC AS, Oslo, Norway) were injected beneath the sediment slurry using a syringe with a long needle. A 2$\mathrm{mL}$ layer of sodium polytungstate solution (Sometu, Berlin, Germany) with a density of $2.23 \mathrm{~g} \mathrm{~mL}^{-1}$ was added beneath the Nycodenz layers. Samples were then centrifuged at 5000 $\times \mathrm{g}$ for $2 \mathrm{~h}$ at $4^{\circ} \mathrm{C}$. After centrifugation, the supernatant above the sodium polytungstate solution was removed with a pipette and kept as "cell extract" in sterile Falcon tubes. Extraction efficiencies (i.e., cell recoveries) were calculated from the number of extracted cells per volume of sediment and the total number of cells per volume of sediment. Enumeration of cells in whole sediment is described in see Section Cell Enumeration. Extraction efficiencies were between $\sim 5$ and $50 \%$.

It has previously been shown that density-based extraction of cells from sediment is representative of the in-situ community at a taxonomic level (Frischer et al., 2000; Braun et al., 2016). To test whether extraction of cells was also representative in terms of cell volume and cell morphology, we compared extracted cells to those in whole sediment in three samples from Landsort Deep and one sample from the Labrador Sea (Supplementary Figure 1). Cell morphology was similar between extracted and non-extracted cells, but the relative amount of coccoid cells was slightly higher in the sediments than in the cell extracts (Supplementary Figure 1A). However, the cell volumes of extracted and non-extracted cells followed a 1:1 line (Supplementary Figure 1B), indicating that extraction of cells from sediment was representative in terms of size.

For measurements of cellular amino acid contents, cell separation was performed as described by Morono et al. (2013). Cell extracts from density centrifugation were then subjected to extensive cell purification using FACS to remove detrital particles as described in Braun et al. (2016).

\section{Cell Enumeration}

Epifluorescence microscopy cell counts were performed on bulk sediment and on cell extracts after cell separation from the sediment matrix. For direct counts (bulk), we usually suspended $0.5 \mathrm{~cm}^{3}$ of sediment in 2-15\% NaCl solution (approximating the salinity of the sample) with $2 \%$ PFA, followed by filtration $(0.2-\mu \mathrm{m}$ pore size polycarbonate membrane filter, Millipore GmbH, Eschborn, Germany) of a small aliquot of the slurry (tens of $\mu \mathrm{L}$ depending on the cell density) and staining with 4',6-diamidin-2-phenylindol (DAPI). Aliquots (10-250 $\mu \mathrm{L}$ ) of cell extracts that had been separated from the sediment were diluted in $\sim 5 \mathrm{~mL}$ Milli-Q water and then directly collected on a polycarbonate membrane filter $(0.2-\mu \mathrm{m}$ pore size) and stained with DAPI. Cells were manually enumerated under an epifluorescence microscope. Generally, either 30 fields of view or at least 200 cells were counted at $1000 \times$ magnification.

\section{Cell Size Determination with FM}

Cell size measurements were performed on the same membrane filters used for cell enumeration. Cell sizes were determined on images acquired with the software AxioVision (Carl Zeiss MicroImaging GmbH, Göttingen, Germany) under 1000× magnification. Since the actual cell boundary could not accurately be distinguished from the surrounding fluorescencehalo, cell lengths, and widths were measured including the fluorescence-halo.

\section{Cell Size Determination with SEM}

Aliquots $(10-250 \mu \mathrm{L})$ of cell extracts were diluted in $\sim 5 \mathrm{~mL}$ Milli-Q water and filtered onto gold-sputtered polycarbonate membrane filters $(0.2-\mu \mathrm{m}$ pore size, $25 \mathrm{~mm}$ diameter, Millipore $\mathrm{GmbH}$, Eschborn, Germany). To keep the cells hydrated, $\sim 1 \mathrm{~mL}$ of the liquid was left on the membrane before it was quickly transferred into $30 \%$ ethanol (in Milli-Q water). The membrane was then subjected to an ethanol-series (30, 50, 70, 80, 99\% ethanol) with $10 \mathrm{~min}$ residence time per concentration. To dry the cells on the filter while retaining their shape, the filter was transferred into a critical point dryer (Leica EM CPD 300, Wetzlar, Germany, slow gas in/out, 14 cycles, heating $40^{\circ} \mathrm{C}$ ). The ethanol was exchanged with liquid $\mathrm{CO}_{2}$ followed by evaporation of the $\mathrm{CO}_{2}$ at the critical point. Samples were then analyzed by SEM (Quanta FEG 250, FEI, Eindhoven, The Netherlands) under high vacuum conditions using an Everhart-Thornley detector (ETD) for secondary electron (SE) imaging and an acceleration voltage of $2 \mathrm{kV}$ for the electron beam. For the imaging process, 128 images were captured each with a dwell time of $100 \mathrm{~ns}$, drift corrected and integrated. Cell sizes were measured on images using the software FEI xT Microscope Control (FEI GmbH, Frankfurt, Germany).

To confirm that cells visualized with SEM retained their 3dimensional shape after dehydration and critical point drying, we took stereoscopic images as well as images before and after tilting the sample table to up to $40^{\circ}$ (Supplementary Figure 2). Even though we cannot exclude that cells have shrunken uniformly due to dehydration and critical point drying, they did not show any signs of flattening, which would have biased the lengths 
and widths measurements (and eventually the volume, since we assumed width $=$ height $)$.

\section{Cell Size Determination with AFM}

For details on the sample preparation, see Section Corrections for Sample Treatments. DimesionIcon (Bruker, Santa Barbara, USA) AFM was used in PeakForce Tapping ${ }^{\mathrm{TM}}$ Mode for structural characterization of the samples. Operation was conducted using triangular silicon nitride cantilever (ScanAsyst Air) with $70 \mathrm{kHz}$ nominal resonant frequency, $0.4 \mathrm{~N} / \mathrm{m}$ nominal spring constant, and $2 \mathrm{~nm}$ nominal tip radius. Cantilevers were calibrated before use. Operation parameters were set in order to achieve highest possible resolution without damaging the sample or the tip. AFM images of 512 points per line with various scan sizes were recorded at a scan rate of $0.5-1 \mathrm{~Hz}$. Multiple images of the same sample from different locations were collected for the best statistical overview. Collected images were processed and analyzed using the open source software Gwyddion (www.gwyddion.net).

\section{Calculations of Cell Volumes and Cell-Specific Carbon Densities}

FM-based cell volumes were calculated for the bacterial shapes coccus, rod, and filament. SEM-based cell volumes also included volumes for prolate spheroids. AFM-based cell volumes, which take into account the individual height of the cells, were calculated based on ellipsoids. The mathematical formulations can be found in the Supplementary Information.

The cell-specific carbon density, $C_{d}$, was calculated by dividing the cell-specific carbon content of a sample by the mean FMbased cell volume. The mean cell volume was determined from the fractions $(f)$ and mean volumes $(V)$ of coccoid, rod-shaped, and filamentous cells per sample according to the following equation:

$$
C_{d}=\frac{\text { Cell-specific carbon content }}{V_{\text {coccus }} \times f_{\text {coccus }}+V_{\text {rod }} \times f_{\text {rod }}+V_{\text {filament }} \times f_{\text {filament }}}
$$

\section{Corrections for Sample Treatments}

Cell sizes were corrected for the following sample treatments or size estimation bias: filtration, fluorescence-halo, fixation, and critical point drying (Table 1). While correction factors for fixation and critical point drying were obtained from the literature, those for filtration and for the fluorescence halo-effect were experimentally determined on cultured E. coli and M. luteus cells.

To obtain a correction factor to account for volume shrinkage from the filtration of cells onto filter membranes, we used fixed ( $2 \%$ PFA for $6 \mathrm{~h}$ at $4^{\circ} \mathrm{C}$ ) E. coli and M. luteus cells. Immediately before the experiment, cells were washed $3 \times$ with Milli-Q water. Aliquots of the cell suspensions were filtered onto gold-sputtered polycarbonate membrane filters $(0.2-\mu \mathrm{m}$ pore size $)$, whereas few drops $(\sim 30 \mu \mathrm{L})$ of the cell suspensions were pipetted onto Siwafers coated with polylysine to immobilize cells on the wafer. When applying drops of cell suspensions onto Si-wafers, the wafers were left in Petri-dishes for about an hour, which allowed
TABLE 1 | Correction factors applied to cell volumes obtained from FM and SEM.

\begin{tabular}{lcccc}
\hline Sample & Fixation & Filtration & Halo-effect & Dehydration and CPD \\
\hline FM-BASED & & & & \\
Coccoid & $1.29^{\star}$ & 1 & 0.475 & n.a. \\
Elongated & $1.29^{\star}$ & 1.13 & 0.475 & n.a. \\
Filamentous & $1.29^{\star}$ & 1.13 & 0.475 & n.a. \\
SEM-BASED & & & & \\
Coccoid & $1.29^{\star}$ & 1 & n.a. & $2.38^{* \star}$ \\
Elongated & $1.29^{\star}$ & 1.13 & n.a. & $2.38^{\star *}$ \\
Filamentous & $1.29^{\star}$ & 1.13 & n.a. & $2.38^{* *}$ \\
\hline
\end{tabular}

${ }^{*}$ Average of values given by Bowden (1977) and Fagerbakke et al. (1996).

${ }^{\star *}$ Average value taken from Bratbak (1985) and references therein.

n.a., not applicable.

cells to settle onto the wafer. The wafer was then gently rinsed with Milli-Q water and transferred into 30\% ethanol solution. During the procedure, great care was taken to ensure that cells on the membrane filters and Si-wafers never dried out and were always immersed in a small amount of liquid. Filters and Si-wafers were then subjected to an ethanol-series and critical point drying as described above. Cell sizes and volumes were calculated from SEM images of $\sim 100$ individual cells for each sample. There was no significant difference between the mean cell volumes of filtered and non-filtered $M$. luteus cells $(P=$ 0.1307 ), but significant volume shrinkage of $11.2 \%$ for $E$. coli cells $(P=0.0408)$. The correction factor for the filtration step was then obtained by dividing the mean cell volumes by each other. For example, the mean cell volume of filtered E. coli cells was $0.68 \mu \mathrm{m}^{3}$, while that of non-filtered E. coli cells was $0.76 \mu \mathrm{m}^{3}$. The cell volumes of filtered elongated cells (rods and filaments) from the sediment samples were therefore corrected by the factor $0.76 / 0.68=1.13$ (Table 1$)$.

To obtain a correction factor for the fluorescence haloeffect (when aureoles appear around the cell; cf. Schumann and Rentsch, 1998), cell suspensions of the cultured E. coli and $M$. luteus cells were filtered onto polycarbonate membrane filters $(0.2-\mu \mathrm{m}$ pore size). The filters were then cut into two halves, one of which was subjected to DAPI-staining and FM imaging, while the other half was mounted onto mica for AFM imaging. AFM imaging required additional blank membrane filters for background correction. Cell sizes and volumes were calculated from FM and AFM images of $\sim 100$ individual cells for each sample. Including the fluorescence-halo into the cell size estimate of $E$. coli cells increased the calculated volume by a factor of 2.1 (cell volumes were therefore corrected by the factor $1 / 2.1=0.48$, Table 1). Unfortunately, aggregation of $M$. luteus cells made size determination with FM impossible. Coccoid cells were therefore corrected with the factor obtained for E. coli cells.

Cell volumes were corrected for cell fixation using the average (22.5\% volume shrinkage) of values given by Bowden (1977) and Fagerbakke et al. (1996). Finally, we corrected for volume shrinkage due to dehydration with ethanol followed by critical point drying by using an average value for shrinkage of $58 \%$ taken from Bratbak (1985) and references therein. We then corrected 
the cell volumes from the investigated sediment samples with the corresponding correction factors (Table 1, Figure 1). Elongated and filamentous cells were corrected with factors obtained for E. coli cells. Coccoid cells in the samples were corrected with factors obtained for M. luteus cells with the exception of the halo-effect, which was corrected with the factor obtained for E. coli cells because aggregation of $M$. luteus cells made size determination with FM impossible. After correction, cell volumes obtained with FM were similar to those obtained with SEM (Figure 1B, Supplementary Figure 3).

\section{HPLC Analysis of Cellular Amino Acids}

HPLC analyses of total hydrolyzable amino acids (THAA) were performed in a special clean lab at the Department of Bioscience, Aarhus University, Denmark. The temperature in the clean lab is constantly held at $21^{\circ} \mathrm{C}$ and HEPA air filters are integrated into the ventilation system. Ultra-clean Milli-Q-water (Milli-Q Integral 3, Millipore) as well as HPLC-grade reagents were used for analysis. All materials were acid-washed $(1 \mathrm{~N} \mathrm{HCl})$ prior to use, and all pipettes/tips were calibrated by weighing $0.005-$ $1 \mathrm{~mL}$ aliquots of Milli-Q water with an accuracy of $\pm 0.0003 \mathrm{~g}$ prior to pipetting of analytes. The concentrations of THAA in FACS-purified cell extracts on ADVANTEC membrane filters and in blank ADVANTEC membrane filters were analyzed by reverse-phase HPLC (Waters Corporation, Eschborn, Germany) of fluorescent o-phthaldialdehyde (OPA)-derivatized products according to the method of Lindroth and Mopper (1979) and with the modifications described in Langerhuus et al. (2012). Briefly, membrane filters were hydrolyzed with $5 \mathrm{~mL} 6 \mathrm{~N} \mathrm{HCl}$ at $105^{\circ} \mathrm{C}$ for $24 \mathrm{~h}$ under $\mathrm{N}_{2}$. Subsamples $(4.5 \mathrm{~mL})$ of hydrolyzate were dried under vacuum at $45^{\circ} \mathrm{C}$, then re-suspended in Milli-Q water, and dried again. Dried samples were then dissolved in $2 \mathrm{~mL}$ Milli-Q water and filtered ( $0.2-\mu \mathrm{m}$ pore size filter; Sartorius). The columns used were a Waters Nova-Pak ${ }^{\circledR}$ guard column $(4 \mu \mathrm{m}$;
$3.9 \times 20 \mathrm{~mm})$ followed by a Waters Nova-Pak ${ }^{\circledR}$ C-18 $(4 \mu \mathrm{m}$; $3.9 \times 150 \mathrm{~mm}$ ) column. Blanks were always prepared along with samples. Blanks that were analyzed along with sediment samples showed negligible target molecule concentrations. Blanks that were prepared and analyzed along with cell extract samples had slightly higher target molecule concentrations, which were subtracted from those in cell extract samples.

\section{RESULTS}

\section{Cell Shapes and Cell Volumes}

For simplification and better comparability between methods, rod-shaped and prolate spheroid cells were grouped as elongated cells. Both methods FM and SEM showed that the majority of cells in the sediment samples were of coccoid or slightly elongated morphology with a length-to-width ratio between 1 and 3 (Figure 2). Long filamentous cells (length:width ratio $>10$ ) were only a minor part of the microbial communities $(<10 \%)$.

SEM imaging of cells was only successful for a subset of the samples. In sediment samples with cell abundances of $<5 \times 10^{8}$ cells $\mathrm{cm}^{-3}$, cell densities on the filter membranes were extremely low and the lack of a fluorescence signal made it extremely difficult to find cells at the high resolution used during SEM imaging. Therefore, we used the corrected FM-based cell volumes for further data presentation and interpretation. The average corrected cell volumes of coccoid and elongated cells significantly decreased with depth (Single factor ANOVA; coccoid cells, $F=23.32, d f=287, P=2.232 \times 10^{-6}$; elongated cells, $F=73.35, d f=382, P=2.699 \times 10^{-16}$ ) from $\sim 0.05$ to $0.006 \mu \mathrm{m}^{3}$ and from $\sim 0.1$ to $0.006 \mu \mathrm{m}^{3}$, respectively (Figures 3A,B). The cell volumes of filamentous cells significantly decreased with depth (Single factor ANOVA; $F=9.815, d f=46, P=0.003009)$ from $\sim 0.3$ to $0.08 \mu \mathrm{m}^{3}$ (Figure 3C). Within samples, the cell volumes of coccoid and
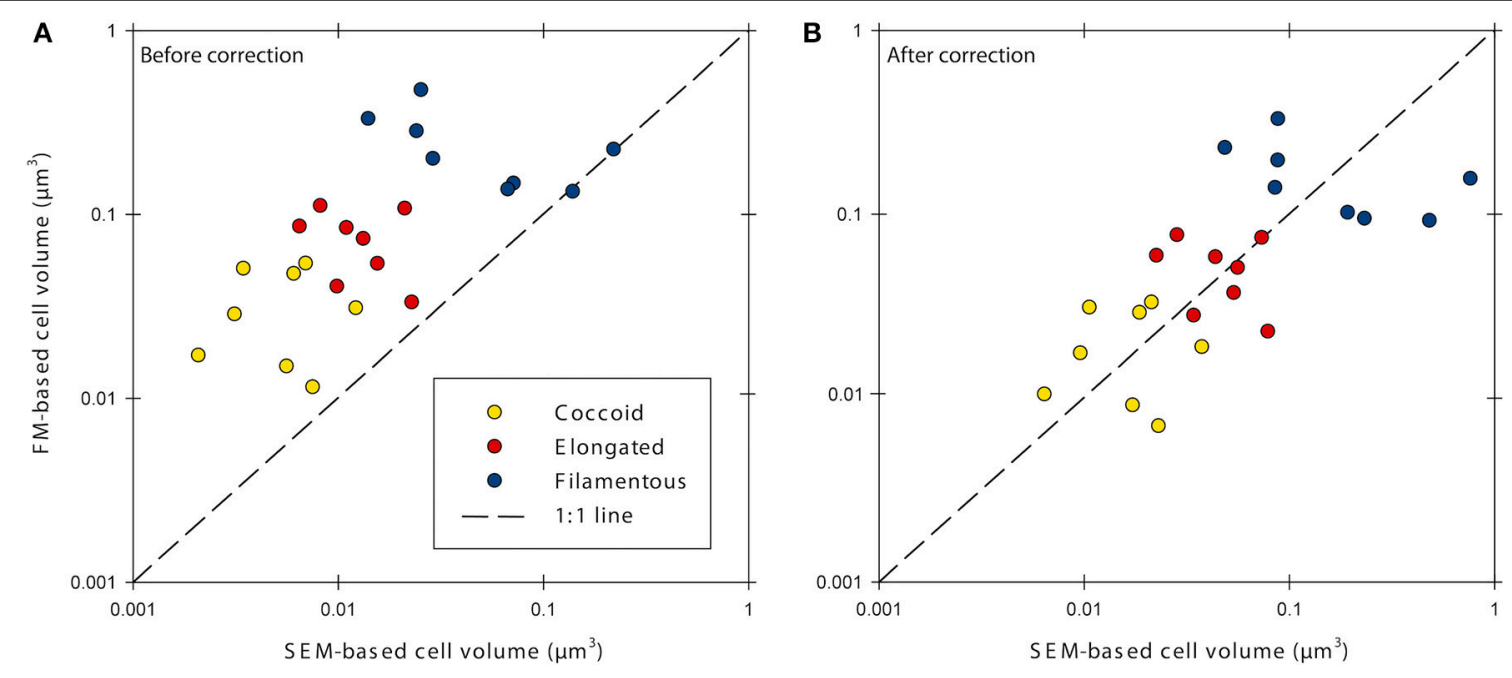

FIGURE 1 | Cell volumes determined with epifluorescence microscopy (FM) and scanning electron microscopy (SEM) before (A) and after (B) correction for errors caused by sample processing. Data was corrected for cell fixation, filtration, dehydration and critical point drying, and the fluorescence-halo effect. 

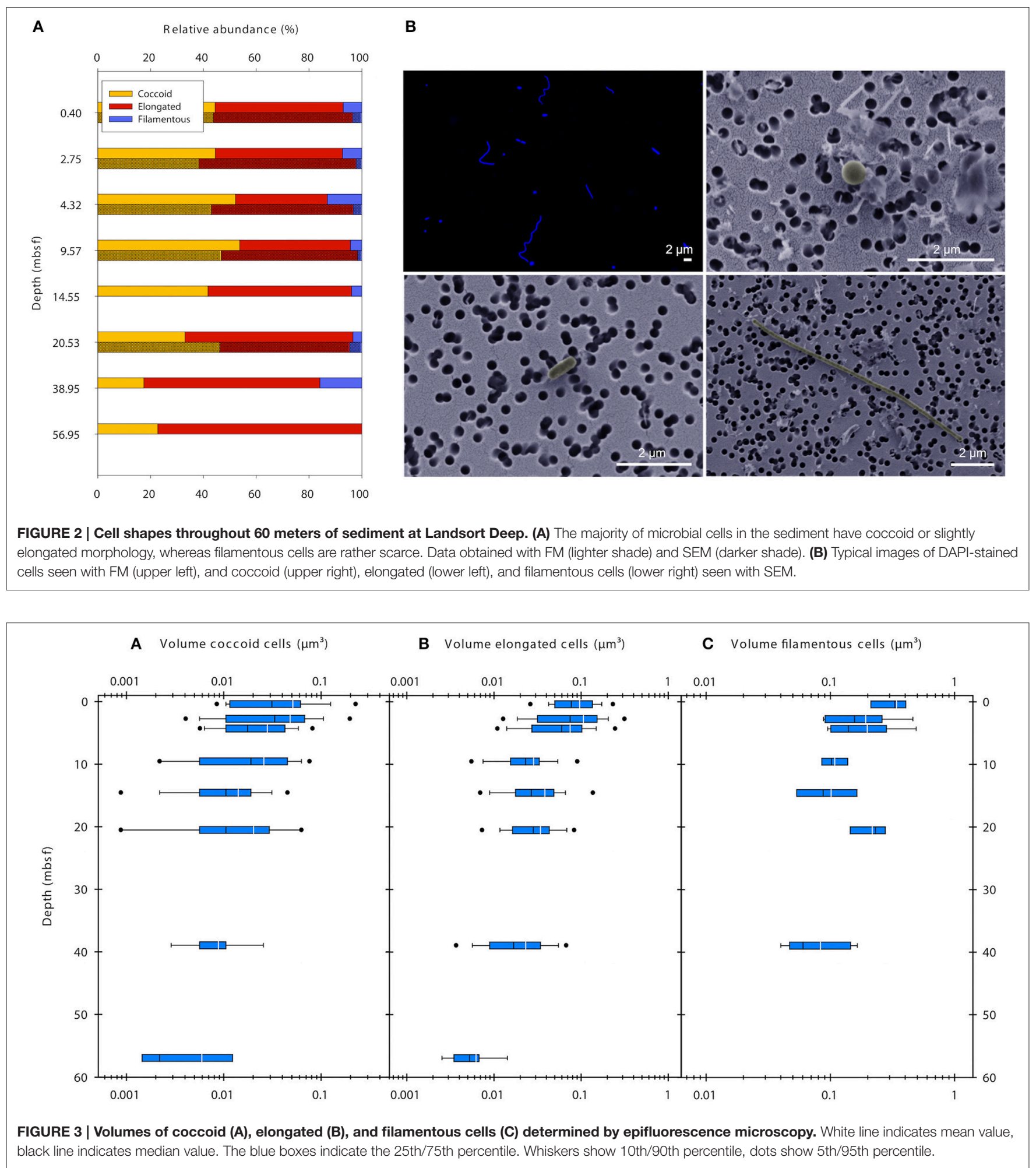

elongated cells typically varied within one order of magnitude, whereas those of filamentous cells varied about half an order of magnitude.

Cell volumes were also determined for three surface sediment samples from the Labrador Sea, where cell abundance was high $\left(>10^{9}\right.$ cells $\left.\mathrm{gdw}^{-1}\right)$ and samples were stored anoxically at $4^{\circ} \mathrm{C}$ instead of $-80^{\circ} \mathrm{C}$ to ensure cell integrity. The data for Labrador Sea samples are included in Figure $\mathbf{1}$ and show a similar pattern as samples from Landsort Deep (see also Supplementary Figure 3B). 


\section{Cell-Specific Carbon Content and Carbon Density}

The cell-specific carbon content was determined for seven samples from Landsort Deep from direct measurements of cellular amino acids (Tables 2, 3). By assuming that amino acidcarbon comprises $\sim 55 \%$ of total cell carbon (Ingraham et al., 1983), the calculated mean cell-specific carbon content was 19-31 fg C cell ${ }^{-1}$. Based on counted cell numbers (Andrén et al., 2015; Supplementary Table 1), the mean carbon content of total microbial cells in the sediment decreased from $350 \mu \mathrm{g} \mathrm{C} \mathrm{cm}^{-3}$ sediment to $<5 \mu \mathrm{g} \mathrm{C} \mathrm{cm}{ }^{-3}$ sediment (Figure 4).

The cell-specific carbon density increased with sediment depth from $\sim 200$ to $600 \mathrm{fg} \mathrm{C} \mu \mathrm{m}^{-3}$, peaking at $1000 \mathrm{fg} \mathrm{C} \mu \mathrm{m}^{-3}$ at $10 \mathrm{~m}$ depth (Figure 5).

\section{DISCUSSION}

\section{Cell-Specific Carbon Content and Carbon Density}

The organic carbon content of bacteria and archaea (mainly from proteins, RNA, lipids, and polysaccharides) can differ strongly among environments and cultures (e.g., Bratbak, 1985; Kogure and Koike, 1987; Simon and Azam, 1989; Fukuda et al., 1998;

\begin{tabular}{|c|c|c|c|}
\hline $\begin{array}{l}\text { Sediment depth } \\
\text { (mbsf) }\end{array}$ & $\begin{array}{c}\text { THAA } \\
\left(\mathrm{fmol} \mathrm{cell}^{-1}\right)\end{array}$ & $\begin{array}{c}\text { THAA-C } \\
\left(\mathrm{fmol}_{\text {cell }}^{-1}\right)\end{array}$ & $\begin{array}{c}\text { Total } C^{\star} \\
\text { (fg C cell-1) }\end{array}$ \\
\hline 0.4 & 0.18 & 0.88 & 19 \\
\hline 2.75 & 0.29 & 1.2 & 26 \\
\hline 4.32 & 0.28 & 1.3 & 29 \\
\hline 9.57 & 0.31 & 1.4 & 31 \\
\hline 14.55 & 0.21 & 0.97 & 21 \\
\hline 20.53 & 0.13 & 0.66 & 14 \\
\hline 38.95 & 0.17 & 0.78 & 17 \\
\hline
\end{tabular}

${ }^{*}$ Calculated from total amino acid-carbon (THAA-C) assuming that THAA-C $=55 \%$ of total cell-carbon (Ingraham et al., 1983).
Lever et al., 2015). For the deep biosphere, global abundance and biomass of microbial cells have been estimated from the available data on cell abundances in the marine subsurface. The first global extrapolation indicated that $94 \%$ of all microbial cells inhabit the deep biosphere and account for a third to half of all living biomass carbon on Earth (Whitman et al., 1998). Based on a larger data set that also included very low cell abundances for the large oligotrophic ocean gyres, Kallmeyer et al. (2012) downscaled these numbers to a global inventory of $2.9 \times$ $10^{29}$ cells, corresponding to $0.18-3.6 \%$ of total global biomass. However, these biomass estimates were not based on direct measurements of the carbon content of sub-seafloor microbial cells. Instead, they were based on mean cellular carbon contents that were deduced from, for example, cell dry weight (Whitman et al., 1998), sedimentary lipid biomarker concentrations (Lipp et al., 2008), or cell volumes (Kallmeyer et al., 2012). While the cell volumes and the lipid concentrations were quantified from actual sub-seafloor samples, the data for the dry weight consisted of one single data point obtained from a terrestrial aquifer (Balkwill et al., 1988). These parameters were then converted into cellular carbon contents using relationships determined for pure cultures or planktonic bacteria from water samples (e.g., Norland et al., 1987; Balkwill et al., 1988; Simon and Azam, 1989).

Our cell extraction and purification procedure allowed us to directly determine the amino acid composition and amino acidcarbon content of the cell extracts. Purification of cell extracts by FACS was important to remove cells from remaining detrital organic particles after Nycodenz-based density centrifugation (Braun et al., 2016). Total cell carbon was then estimated for all samples by assuming that amino acids contain 55\% of total cell carbon (Ingraham et al., 1983). The cell-specific carbon content in our samples from Landsort Deep ranged from 19 to $31 \mathrm{fg} \mathrm{C}$ cell $^{-1}$, with a mean value of $23 \mathrm{fg} \mathrm{C} \mathrm{cell}^{-1}$. This estimate is at the lower end of those for eutrophic estuarine and coastal systems (Bratbak, 1985; Bjørnsen, 1986; Kogure and Koike, 1987; Lee and Fuhrman, 1987; Kroer, 1994), but similar to those for starved laboratory cultures or the oligotrophic open ocean (e.g., Simon and Azam, 1989; Fukuda et al., 1998). Notably, our new estimate is 3-4 times lower than widely used previous estimates for marine sediments of $65 \mathrm{fg} \mathrm{C}^{-1}$ cell $^{-1}$ (Parkes et al.,

TABLE 3 | Mole percentage composition for each hydrolysable amino acid in cell extract samples from Landsort Deep, Baltic Sea.*

\begin{tabular}{|c|c|c|c|c|c|c|c|c|c|c|c|c|c|c|c|c|c|c|}
\hline \multirow[t]{2}{*}{ Depth (mbsf) } & \multicolumn{18}{|c|}{ Mole \% } \\
\hline & Asp & Glu & Ser & His & Gly & Thr & Arg & $\beta$-Ala & Tau & Ala & $\gamma$-Aba & Tyr & Val & Phe & Ileu & Leu & Orn & Lys \\
\hline 0.4 & 5.8 & 8.5 & 8.1 & 0.9 & 11.7 & 9.1 & 5.1 & n.d. & n.d. & 14.2 & n.d. & 3.1 & 8.4 & 5.0 & 4.4 & 10.3 & n.d. & 5.2 \\
\hline 2.75 & 5.0 & 8.4 & 13.0 & 0.7 & 31.5 & 5.2 & 3.7 & n.d. & n.d. & 8.4 & n.d. & 2.8 & 4.4 & 3.4 & 2.2 & 6.7 & n.d. & 4.7 \\
\hline 4.32 & 4.5 & 8.8 & 10.5 & 0.9 & 14.0 & 6.8 & 5.8 & n.d. & n.d. & 10.6 & n.d. & 3.6 & 6.9 & 3.6 & 10.0 & 8.8 & n.d. & 5.2 \\
\hline 9.57 & 9.4 & 12.3 & 11.8 & 1.0 & 18.3 & 4.7 & 4.7 & n.d. & n.d. & 7.6 & n.d. & 3.2 & 5.0 & 3.5 & 3.0 & 10.2 & n.d. & 5.4 \\
\hline 14.55 & 5.8 & 7.5 & 7.7 & 0.6 & 13.2 & 8.5 & 4.4 & n.d. & n.d. & 16.0 & n.d. & 2.8 & 8.5 & 5.0 & 4.0 & 10.3 & n.d. & 5.9 \\
\hline 20.53 & 10.9 & 10.7 & 5.1 & 0.9 & 7.5 & 7.2 & 4.6 & n.d. & n.d. & 16.0 & n.d. & 2.9 & 8.8 & 4.9 & 3.8 & 12.0 & n.d. & 4.7 \\
\hline 38.95 & 10.0 & 14.1 & 11.7 & 1.2 & 14.4 & 4.7 & 5.2 & n.d. & n.d. & 6.7 & n.d. & 3.4 & 5.5 & 3.8 & 1.3 & 12.5 & n.d. & 5.5 \\
\hline
\end{tabular}

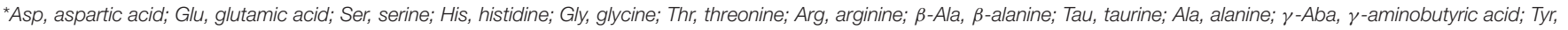
tyrosine; Val, valine; Phe, phenylalanine; lleu, isoleucine; Leu, leucine; Orn, ornithine; Lys, lysine; n.d., not detected. 


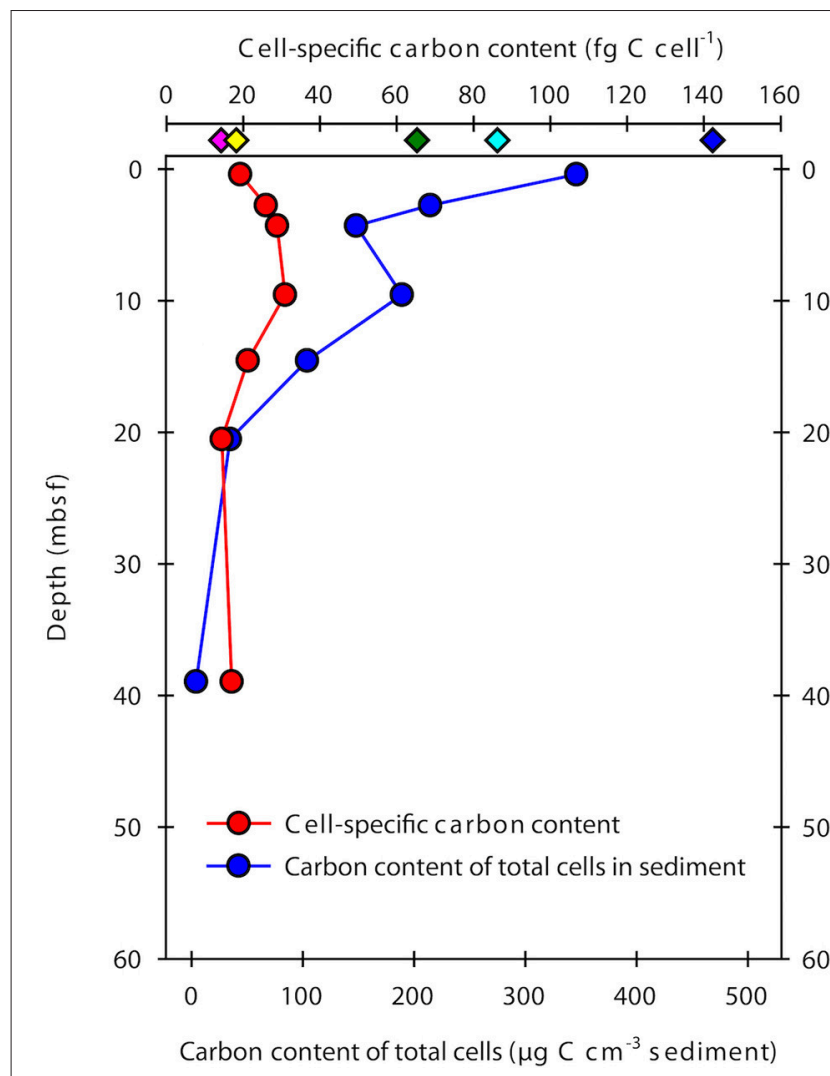

FIGURE 4 | Cell-specific carbon content and total microbial cell carbon in samples from Landsort Deep. The cell-specific carbon content (red symbols) was determined from direct measurements of cellular amino acids, assuming these comprise $\sim 55 \%$ of total cell carbon (Ingraham et al., 1983). Diamond symbols at the top indicate previously estimated cellular carbon contents for sub-seafloor cells (green, Parkes et al., 1994; cyan, Whitman et al., 1998; yellow, Lipp et al., 2008; pink, Kallmeyer et al., 2012) and for FACS-purified E. coli cells (blue, Braun et al., 2016). The carbon content of total microbial cells in the sediment (blue circle symbols) was obtained by multiplying the mean cell-specific carbon content with the number of DNA stainable microbial cells (Andrén et al., 2015).

1994) and $86 \mathrm{fg} \mathrm{C}^{-1} \mathrm{cell}^{-1}$ (Whitman et al., 1998) and 6 times lower than the carbon content of cells sorted from an E. coli culture (Braun et al., 2016; Figure 4), which was analyzed in the same way as the samples from this study. However, our new estimate is higher than the $14 \mathrm{fg} \mathrm{C} \mathrm{Cell}^{-1}$ used for the most recent global estimate of microbial biomass (Kallmeyer et al., 2012). The estimate of Kallmeyer et al. (2012) was based on cell volumes determined by fluorescence microscopy for sediment samples from the oligotrophic South Pacific Gyre. The conversion from volumes to carbon contents was established from relationships between cell size and protein content of pelagic bacteria (Simon and Azam, 1989), which may not be appropriate for the deep biosphere. A mean value of $14 \mathrm{fg} \mathrm{C} \mathrm{cell}^{-1}$, however, may indicate that cells that live under energy-deprived conditions have a lower cell-specific carbon content than cells that live in environments with higher amounts of available energy from organic matter. At Landsort Deep, TOC concentrations decrease from $\sim 3 \%$ at the sediment surface to $\sim 0.2 \%$ at $60 \mathrm{mbsf}$ (Figure 6). In contrast,

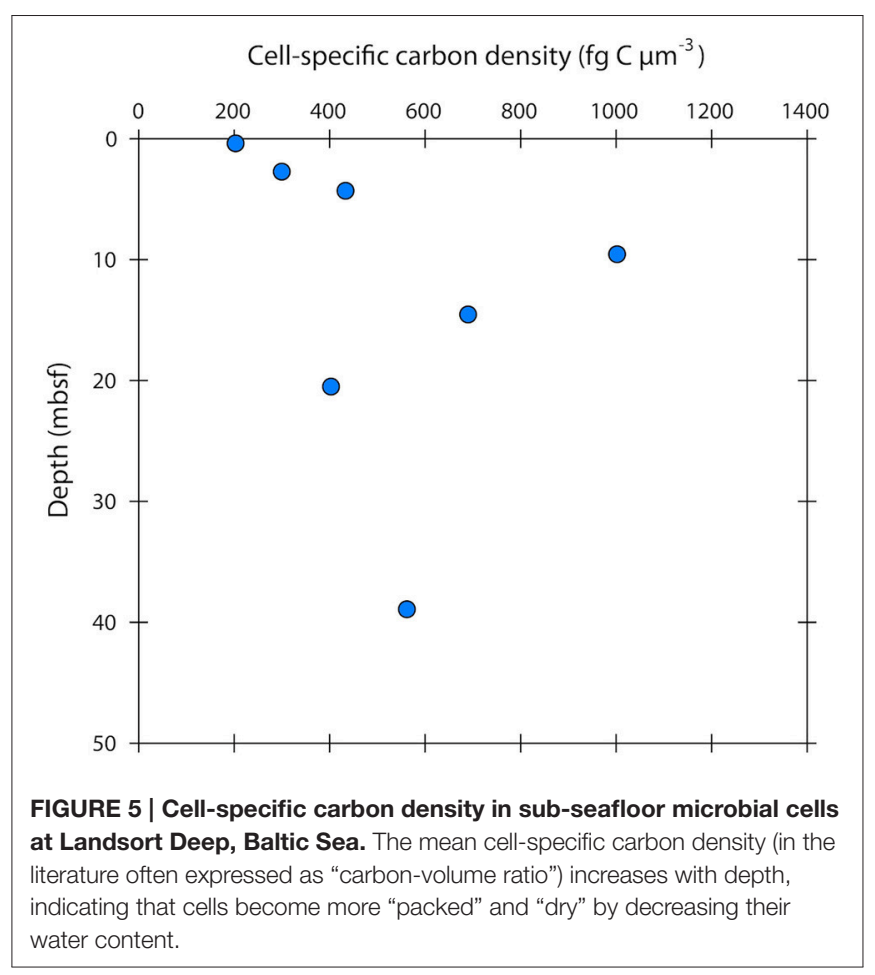

TOC concentrations in the South Pacific Gyre are $~ 0.3-0.5 \%$ at the sediment surface and slowly decline to $<0.1 \%$ at $5 \mathrm{mbsf}$. Our estimate and that of Kallmeyer et al. (2012) seem very close to each other when considering the enormous difference of the sediment ages. Due to the low sedimentation rates of $<0.1 \mathrm{~cm} \mathrm{kyr}^{-1}$ in the South Pacific Gyre (D'Hondt et al., 2009), the sediment age at a depth of $5-10$ mbsf is $25-100$ million years (D'Hondt et al., 2009). At Landsort Deep, sedimentation rates are $100-500 \mathrm{~cm} \mathrm{kyr}^{-1}$, and the age of the sediment column investigated here is $<15,000$ years (Andrén et al., 2015). Thus, it appears that the cell-specific carbon content in marine sediments is a relatively constant parameter, possibly because the cells require a minimum set of macromolecules to remain functional.

Our assumption that amino acids contain 55\% of total cell carbon (Ingraham et al., 1983) does not change the relative differences between the cell-specific (amino acid-) carbon contents between the samples since we used the same assumption for all of the samples. However, multiplying cellular amino acidcarbon (AA-C) by a factor of $1 / 0.55=1.82$ is based on cultures of E. coli (Ingraham et al., 1983). Cells in the deep biosphere may have a different AA-C/total-C ratio than cultured E. coli cells. Even though literature about these ratios in prokaryotes from environmental sample is scarce, we suggest that the AA-C/total$\mathrm{C}$ ratio of $55 \%$ is appropriate based on the study by Simon and Azam (1989). The authors studied cell sizes and protein (amino acids) contents in pelagic bacteria and-based on the cellular fractions of other macromolecular pools such as the cell wall, cell membrane, and nucleic acids - estimated cell dry weight and total cell carbon. Throughout the samples, the cell protein:dry weight and cell carbon:dry weight ratios were essentially constant (63 and $54 \%$, respectively), although mean cell diameters ranged over 


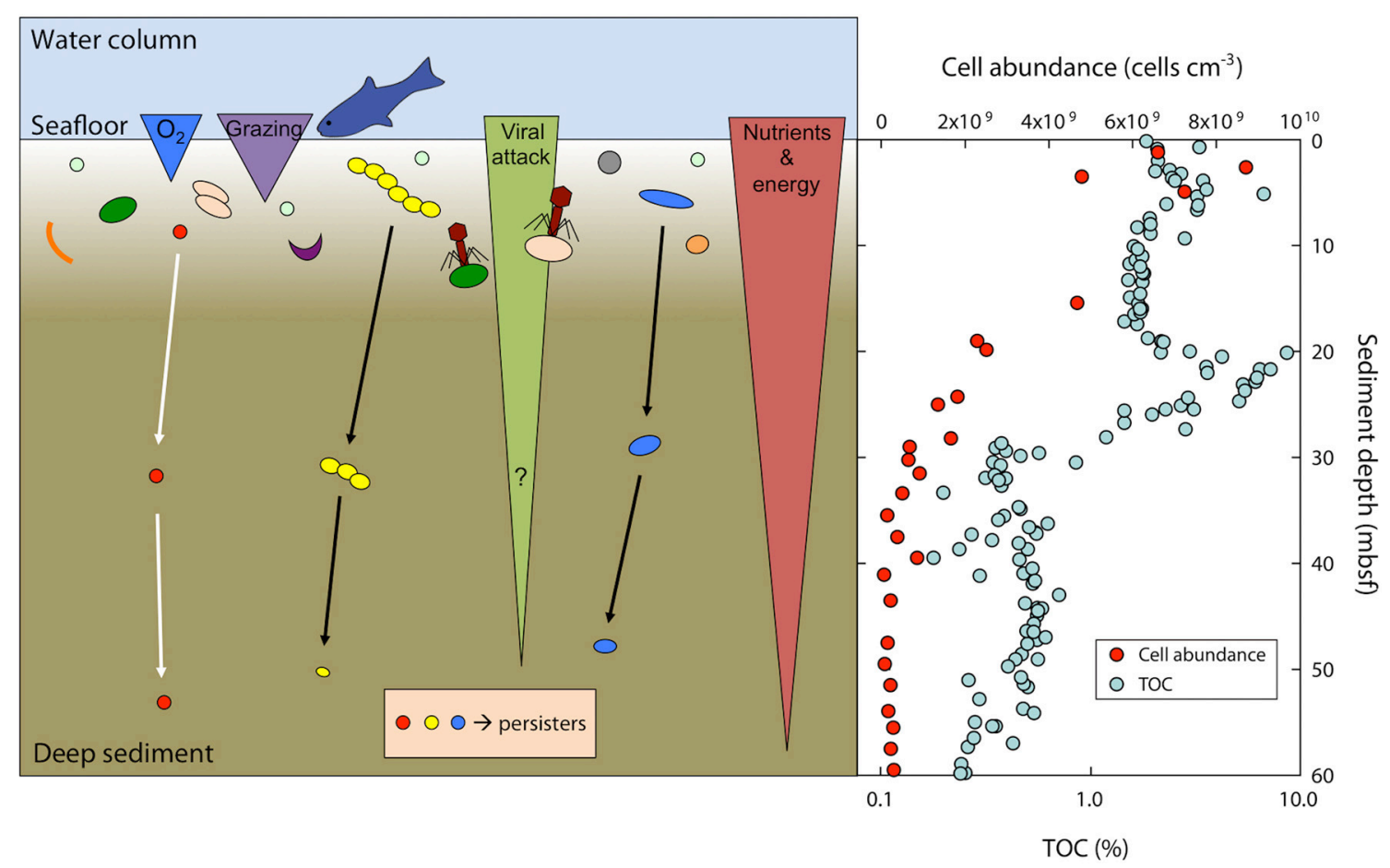

FIGURE 6 | Scheme of the survival and size-adaptation of cells during burial in marine sediments. Typically, about $90 \%$ of the surface community dies within a few $\mathrm{mm}$ to $\mathrm{cm}$ of burial due to a variety of factors such as predation (grazing), viral attack, oxygen levels, toxic waste products, or nutrient and energy limitation (left panel). A small subset of the surface population is able to survive at the harsh conditions faced during burial and will further adapt by growing small cell sizes to reduce maintenance costs. Note that bacterial size and their absolute abundance are not to scale. Total cell abundance (acridine orange direct counts, AODC) is steeply decreasing in sediments at Landsort Deep (right panel). Total organic carbon (TOC) deposited from the surface photosynthetic world serves as electron donor and energy source and is decreasing with sediment depth at Landsort Deep (right panel). Data for cell abundance and TOC taken from Andrén et al. (2015).

one order of magnitude from 0.026 to $0.4 \mu \mathrm{m}$. Most importantly, cell carbon had a constant relationship with cell protein. On average, the ratio between cellular amino acid-carbon and total cell-carbon was $61 \%$, which is only slightly higher than the 55\% we have used for our samples.

If the amino acids in the cells investigated in this study contained more than 55\% of total cell-C, the total cell-specific carbon contents would be lower than the values reported here. For example, when we assume that AA-C makes up 75\% (instead of $55 \%$ ) of total cell-C in the deepest of our samples, the cellspecific carbon content would be $13 \mathrm{fg} \mathrm{C}$ cell $^{-1}$ (instead of $17 \mathrm{fg} \mathrm{C}$ cell $^{-1}$ ). Yet, the difference of $4 \mathrm{fg} \mathrm{C}$ cell $^{-1}$ is still small compared to the differences to the widely used previous estimates for marine sediments of $65 \mathrm{fg} \mathrm{C}^{-1}$ cell $^{-1}$ (Parkes et al., 1994) and $86 \mathrm{fg} \mathrm{C}$ cell $^{-1}$ (Whitman et al., 1998). Since protein is a major macromolecule with essential functions in cells, it is unlikely that it makes up only a small fraction of the cell biomass. However, a AA-C/total cell-C ratio of, for example, $40 \%$ would result in a cell-specific carbon content of $23 \mathrm{fg} \mathrm{C} \mathrm{cell}^{-1}$ for the deepest investigated sample in this study. Even though this value exceeds our estimate by $6 \mathrm{fg} \mathrm{C}$ cell $^{-1}$, it is still much lower than the estimates by Parkes et al. (1994) and Whitman et al. (1998). Notably, the mean cell-specific carbon content of $14 \mathrm{fg} \mathrm{C}$ cell $^{-1}$ that was used for the most recent global microbial biomass estimate by Kallmeyer et al. (2012) seems to be a realistic estimate of the carbon content of deep biosphere cells.

Our new estimates of the mean cell-specific carbon content will also be important for estimating microbial generation times in the deep biosphere (Langerhuus et al., 2012; cf. Lomstein et al., 2012; Hoehler and Jørgensen, 2013). These are typically calculated from cell-specific carbon assimilation rates and assumed cellular carbon contents and growth yields. Carbon assimilation rates are often calculated from activity measurements using radiotracers such as ${ }^{35} \mathrm{~S}$-labeled sulfate for sulfate reduction and ${ }^{14} \mathrm{C}$-labeled bicarbonate or acetate for methanogenesis (e.g., Parkes et al., 1990). Cells with a high cellspecific carbon content need to assimilate more carbon to renew all cell-carbon than those cells that have low carbon contents. Cell-carbon turnover times are in the order of years to hundreds of years when an elevated cell-specific carbon content of $88 \mathrm{fg} \mathrm{C}$ cell $^{-1}$ (Langerhuus et al., 2012; Lomstein et al., 2012) or $65 \mathrm{fg}$ $\mathrm{C} \mathrm{cell}^{-1}$ (Hoehler and Jørgensen, 2013) is used. Using our new mean estimate of $23 \mathrm{fg} \mathrm{C}^{-1} \mathrm{cell}^{-1}$, turnover times will be 3-4 times lower than the previous estimates.

Few studies have measured cell-specific carbon contents in low energy environments, and these have shown low values with a small range of variation as we have shown here (Fukuda et al., 1998; Vrede et al., 2002). Biovolume decrease and cell shrinkage 
are more commonly used indications of energy limitation (Lever et al., 2015). Concurrently, the cell-specific carbon density has been shown to increase upon starvation in various cultured marine and non-marine strains (Nagata and Watanabe, 1990; Troussellier et al., 1997). The cell-specific carbon density that we observed in our cell extracts increased with sediment depth

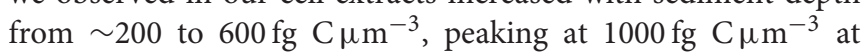
$10 \mathrm{~m}$ depth (Figure 5). These carbon densities are consistent with those reported from natural bacterial assemblages of $130-1600 \mathrm{fg}$ C $\mu \mathrm{m}^{-3}$ (Bratbak, 1985; Bjørnsen, 1986; Lee and Fuhrman, 1987; Simon and Azam, 1989; Kroer, 1994). For comparison, the carbon density in growing $E$. coli cells, and in several other growing cultures, is typically $<100 \mathrm{fg} \mathrm{C}^{-3}$ (Fagerbakke et al., 1996). The cell-specific carbon density has been shown to increase with decreasing cell volume (Simon and Azam, 1989; Troussellier et al., 1997), but also seems to be species dependent and greatly affected by energy conditions (Troussellier et al., 1997). Elevated cell-specific carbon densities imply low cellular water contents. Simon and Azam (1989) reported that marine diminutive bacteria with volumes around $0.03 \mu \mathrm{m}^{3}$ had a very low water content of only $46 \%$ (v:v), whereas larger bacteria $\left(0.4 \mu \mathrm{m}^{3}\right)$ had a high water content of $82 \%$ (v:v). Interestingly, the cell carbon:dry weight ratio was essentially constant throughout the range of cell sizes. Microbes with diminutive volumes might therefore change their cell size by disproportionally varying the water content as compared to the biomass, thus reducing energetic costs (Simon and Azam, 1989). Given the large range of variation in the cell-specific carbon density, cell-specific carbon contents obtained solely from measured cell volumes, and the use of general conversion factors can have large error bars.

\section{Cell Volume}

Microorganisms commonly found in natural environments such as soils, freshwater lakes and rivers, estuarine and brackish waters, coastal and nearshore marine waters, or pelagic marine waters generally have cell volumes between 0.05 and $0.5 \mu \mathrm{m}^{3}$ (cf. reviews by Romanova and Sazhin, 2010; Lever et al., 2015). These volumes are typically $2-10$-fold lower than those of cells in growing pure cultures (e.g., Trueba and Woldringh, 1980; Montesinos et al., 1983; Troussellier et al., 1997). The mean cell volumes in sediments at Landsort Deep are 0.007$0.095 \mu \mathrm{m}^{3}$, which is up to an order of magnitude lower than those reported for microbes in freshwater lakes or energy-rich coastal waters and are closer to those from the oligotrophic open ocean (Børsheim, 1990). The volumes are similar to the mean cell volume of $0.042 \mu \mathrm{m}^{3}$ in deep old marine sediments determined by Kallmeyer et al. (2012). The energy-deprived deep biosphere is characterized by selective pressure (Starnawski, 2016) and extremely low metabolic rates (e.g., D'Hondt et al., 2004; Schippers et al., 2005; Jørgensen and D'Hondt, 2006; Langerhuus et al., 2012; Lomstein et al., 2012; Røy et al., 2012) that allow cell division only on annual to centennial timescales (reviewed in Hoehler and Jørgensen, 2013; Jørgensen and Marshall, 2016). Cells from pure cultures typically respond to experimental energy limitation by reducing their cell size and volume within days to weeks, either by shrinking (Novitsky and Morita, 1976; Kieft et al., 1997) or by fragmentation, that is, cell division without growth (Amy and Morita, 1983; Amy et al., 1993). When considering the physiological state of cells in the energy-limited, but extremely stable deep biosphere, comparisons with acute stress responses of cultured cells are, however, misleading. Cells in the deep biosphere live under balanced conditions at extremely low metabolic rates, comparable to a chemostat culture that grows for many generations under constant conditions over weeks or months (Hoehler and Jørgensen, 2013; Jørgensen and Marshall, 2016). The cells are in physiological balance (i.e., stable growth rate, unchanging macromolecular composition such as the composition of membrane lipids, etc.) while being energetically constrained in their metabolic rate. About $90 \%$ of the surface community dies within a few $\mathrm{mm}$ to $\mathrm{cm}$ of burial (e.g., Langerhuus et al., 2012; Figure 6) due to a variety of factors such as predation, viral attack, oxygen levels, toxic waste products, or nutrient and energy limitation. A small subset of the surface population is, however, pre-adapted to the harsh conditions faced during burial (Starnawski, 2016). These cells survive burial and will further adapt to the environmental conditions during burial (Figure 6). In deep sediments, the community size decreases only marginally $(<1 \%)$ per generation (Jørgensen and Marshall, 2016), and cells are slowly selected for properties that enhance nutrient uptake, facilitate ATP synthesis, reduce energy loss (e.g., leakage of protons through the cell membrane), and counteract biomolecule decay over thousands to millions of years. Since cells in the deep biosphere are predominantly very small (i.e., $<0.05 \mu \mathrm{m}^{3}$ ), they may have been selected for because small "packed" cells with a low water content (see also Section Cell-Specific Carbon Content and Carbon Density) may be less prone to intracellular damage from chemical reactions such as amino acid racemization, protein denaturation, or DNA depurination. The cells may also actively adapt to the energy-limiting conditions by growing small cell sizes to minimize maintenance requirements (Oliver, 1993; Figure 6). Furthermore, subcellular architecture might be preserved due to the protective, glass-like properties of the bacterial cytoplasm at low metabolic activity (Parry et al., 2014).

The reduction in cell size leads to an increased surfaceto-volume ratio. In the oligotrophic water column, cells often increase their surface-to-volume ratio to facilitate the uptake of scarce substrates (Gottschal, 1992). In the deep biosphere, however, it is unlikely that the reduction in cell size considerably affects the uptake of substrates because they are turned over very slowly. The transport over the cell wall, and thereby the surfaceto-volume ratio itself, is probably not the main competitive control. Glombitza et al. (2015) calculated that the turnover and diffusion times of volatile fatty acids (VFAs, e.g., acetate) at several meters depth in sediments offshore southwest Greenland. While VFA diffusion times were short (below $0.5 \mathrm{~s}$ ), their turnover times were up to a year, showing that diffusion is not limiting VFA turnover. Under these conditions, cell physiological constraints such as the energetic costs of VFA activation or uptake may be a limiting factor in substrate turnover rather than kinetic constraints due to cell surface area or cell volume.

Even though observed differences in cell volumes may arise due to a variety of environmental factors such as energy, 
nutrients, and redox conditions, they may also be the result of methodological problems. While a large body of data exists from around the World Ocean, based on fluorescence microscopy of DNA stained cells, a number of studies have addressed advantages and disadvantages of cell size estimations with FM or SEM (cf. Fuhrman, 1981; Bratbak, 1993; Bölter et al., 2002; Malfatti et al., 2010; Romanova and Sazhin, 2010). These studies usually included recommendations for sample treatments and analyses to account for measurement artifacts. For example, fluorescent latex spheres of known diameter have widely been used to calibrate sizes of objects that are surrounded by aureoles (e.g., Bratbak, 1993; Loferer-Krößbacher et al., 1998; Pelegri et al., 1999). Size measurements of sub-micrometer microbial cells within an environmental matrix ideally involve a fluorescent label for clear identification of cells, combined with the spatial resolution of a scanning electron microscope. Even though it is possible to combine SEM or AFM with FM for better identification of cells, several correction factors need to be used in order to account for the remaining artifacts from sample preparations. In our study, we used correction factors obtained from the literature or from experiments with cultured cells. Since cultured cells may show different responses to sample treatments than deep biosphere cells, the appropriateness of the correction factors can be questioned. For example, the mean literature value used to correct for dehydration and CPD was based on cultured cells (Bratbak, 1985), which probably had a higher water content than deep biosphere cells and may have been more prone to shrinkage upon dehydration. However, since the corrected FM- and SEM-based cell volumes in our study do compare, we conclude that the correction factors were appropriate. Superresolution fluorescence microscopy that operates beyond the diffraction barrier imposed by the wave nature of light, such as photoactivated localization microscopy (PALM), stochastic optical reconstruction microscopy (STORM), and stimulated emission depletion (STED) microscopy (cf. Hell, 2009; Coltharp and Xiao, 2012), have not been used in deep biosphere research yet. However, these techniques could-upon the development of suitable fluorophores for cell tagging (Klar et al., 2000)overcome problems faced with FM, SEM, or AFM, and may reduce the need for correction factors.

\section{CONCLUSION}

Our data showed that average cell volumes decreased with sediment depth by up to one order of magnitude and were 10-100 times smaller than those of growing E. coli cells. Based on measurements of cellular amino acids, estimates of the cellspecific carbon content were $19-31 \mathrm{fg} \mathrm{C}^{-1} \mathrm{cell}^{-1}$. The data verifies a low but relatively constant cell-specific carbon content as a general feature of subsurface microbial life. The cell-specific

\section{REFERENCES}

Amy, P. S., Durham, C., Hall, D., and Haldeman, D. L. (1993). Starvationsurvival of deep subsurface isolates. Curr. Microbiol. 26, 345-352. doi: 10.1007/ BF01576267 carbon density was increasing with sediment depth and therefore the water content was decreasing. Microbial communities in the deep biosphere grow and multiply with extremely low rates of metabolism. Growing small cell sizes (i.e., in this context, $<0.05 \mu \mathrm{m}^{3}$ ) seems to be one of probably many adaptations of sub-seafloor microbial life to energy limitation.

\section{AUTHOR CONTRIBUTIONS}

SB, MD, SL, MK, BJ, and BL designed the study; SB, YM, SL, and HA performed the laboratory work; $\mathrm{SB}$ and HA performed data analysis; SB wrote the manuscript; BL, BJ, YM, SL, and MK edited the manuscript.

\section{ACKNOWLEDGMENTS}

We thank Lykke Poulsen, Octavian Andrei Istrate, and Snehit S. Mhatre for skillful technical assistance and guidance with high-performance liquid chromatography analysis, and we thank Daniela Tienken for support in sample preparation for SEM. We thank Anne Stentebjerg for advice in culturing cells. We would like to thank Associate Editor JB for editing the manuscript. We would like to thank the two reviewers BR and AS for their helpful comments and suggestions on an earlier version of this manuscript. This work was supported by a European Research Council Advanced Grant (MICROENERGY) given to BJ under the European Union's Seventh Framework Programme (FP7/2007-2013)/ERC Grant Agreement no 294200. Further support was provided from the Danish National Research Foundation (DNRF)/grant agreement no DNRF104, and the Graduate School of Science and Technology at Aarhus University. This work was also supported in part by JSPS KAKENHI Grant Number 15H05608, 16K14817, and 24651018 to YM. We gratefully acknowledge the contributions of Arctic Research Centre (ARC), Aarhus University. Support was also provided by the Canada Excellence Research Chair (CERC). We are grateful to the Max-Planck-Society for supporting the SEM facility at the MPI Bremen. All participants of the sampling expedition to the Godthåbsfjord in Greenland and the crew members of the $R / V$ Sanna are gratefully acknowledged. This research used samples provided by the Integrated Ocean Drilling Program (IODP). We thank the crew and scientific team of IODP Leg 347.

\section{SUPPLEMENTARY MATERIAL}

The Supplementary Material for this article can be found online at: http://journal.frontiersin.org/article/10.3389/fmicb. 2016.01375

Amy, P. S., and Morita, R. Y. (1983). Starvation-survival patterns of sixteen freshly isolated open-ocean bacteria. Appl. Environ. Microbiol. 45, 1109-1115.

Andrén, T., Jørgensen, B. B., Cotterill, C., Green, S., and Exped. 347 Scientists (2015). "Baltic sea paleoenvironment," in Proceedings of the Integrated Ocean 
Drilling Program, Vol. 347 (Tokyo: Integr. Ocean Drill. Program Manag. Int.). Available online at: http://publications.iodp.org/proceedings/347/347title.htm Balkwill, D. L., Leach, F. R., Wilson, J. T., McNabb, J. F., and White, D. C. (1988). Equivalence of microbial biomass measures based on marine lipid and cell wall components, adenosine triphosphate, and direct cell counts in subsurface aquifer sediments. Microb. Ecol. 16, 73-84. doi: 10.1007/BF020 97406

Bjørnsen, P. K. (1986). Automatic determination of bacterioplankton biomass by image analysis. Appl. Environ. Microbiol. 51, 1199-1204.

Bölter, M., Bloem, J., Meiners, K., and Möller, R. (2002). Enumeration and biovolume determination of microbial cells - a methodological review and recommendations for applications in ecological research. Biol. Fertil. Soils 36, 249-259. doi: 10.1007/s00374-002-0537-6

Børsheim, K. Y. (1990). Bacterial biomass and production rates in the Gulf Stream front regions. Deep Sea Res. 37, 1297-1309. doi: 10.1016/0198-0149(90) 90044-V

Bowden, W. B. (1977). Comparison of two direct-count techniques for enumerating aquatic bacteria. Appl. Environ. Microbiol. 33, 1229-1232.

Bratbak, G. (1985). Bacterial biovolume and biomass estimations. Appl. Environ. Microbiol. 49, 1488-1493.

Bratbak, G. (1993). "Microscope methods for measuring bacterial biovolume: epifluorescence microscopy, scanning electron microscopy, and transmission electron microscopy," in Handbook of Methods in Aquatic Microbial Ecology, eds P. F. Kemp, B. F. Sherr, E. B. Sherr, and J. J. Cole (Boca Raton, FL: Lewis Publishers), 309-317.

Braun, S., Morono, Y., Becker, K. W., Hinrichs, K.-U., Kjeldsen, K. U., Jørgensen, B. B., et al. (2016). Cellular content of biomolecules in sub-seafloor microbial communities. Geochim. Cosmochim. Acta 188, 330-351. doi: 10.1016/ j.gca.2016.06.019

Coltharp, C., and Xiao, J. (2012). Superresolution microscopy for microbiology. Cell Microbiol. 14, 1808-1818. doi: 10.1111/cmi.12024

D’Hondt, S., Jørgensen, B. B., Miller, D. J., Batzke, A., Blake, R., Cragg, B. A., et al. (2004). Distributions of microbial activities in deep subseafloor sediments. Science 306, 2216-2221. doi: 10.1126/science. 1101155

D'Hondt, S., Spivack, A. J., Pockalny, R., Ferdelman, T. G., Fischer, J. P., Kallmeyer, J., et al. (2009). Subseafloor sedimentary life in the South Pacific Gyre. Proc. Natl. Acad. Sci. U.S.A. 106, 11651-11656. doi: 10.1073/pnas.08117 93106

Expedition 347 Scientists (2014). Baltic Sea Basin Paleoenvironment: Paleoenvironmental Evolution of the Baltic Sea Basin through the Last Glacial Cycle. Integrated Ocean Drilling Program Expedition 347 Preliminary Report, IODP.

Fagerbakke, K. M., Heldal, M., and Norland, S. (1996). Content of carbon, nitrogen, oxygen, sulfur and phosphorus in native aquatic and cultured bacteria. Aquat. Microb. Ecol. 10, 15-27. doi: 10.3354/ame010015

Frischer, M. E., Danforth, J. M., Healy, M. A. N., and Saunders, F. M. (2000). Whole-Cell versus total RNA extraction for analysis of microbial community structure with 16S rRNA-targeted oligonucleotide probes in salt marsh sediments. Appl. Environ. Microbiol. 66, 3037-3043. doi: 10.1128/AEM.66.7. 3037-3043.2000

Fuhrman, J. A. (1981). Influence of method on the apparent size distribution of bacterioplankton cells: epifluorescence microscopy compared to scanning electron microscopy. Mar. Ecol. Prog. Ser. 5, 103-106. doi: 10.3354/meps005103

Fukuda, R., Ogawa, H., Nagata, T., and Koike, I. (1998). Direct determination of carbon and nitrogen contents of natural bacterial assemblages in marine environments. Appl. Environ. Microbiol. 64, 3352-3358.

Glombitza, C., Jaussi, M., Røy, H., Seidenkrantz, M., Lomstein, B. A., and Jørgensen, B. B. (2015). Formate, acetate and propionate as substrates for sulfate reduction in sub-arctic sediments of Southwest Greenland. Front. Microbiol. 6:846. doi: $10.3389 /$ fmicb. 2015.00846

Gottschal, J. C. (1992). Substrate capturing and growth in various ecosystems. J. Appl. Bacteriol. Symp. 73, 39s-48s.

Hell, S. W. (2009). Microscopy and its focal switch. Nat. Methods 6, 24-32. doi: 10.1038/nmeth.1291

Hoehler, T. M., and Jørgensen, B. B. (2013). Microbial life under extreme energy limitation. Nat. Rev. Microbiol. 11, 83-94. doi: 10.1038/nrmicro2939

Ingraham, J. L., Maaløe, O., and Neidhardt, F. C. (1983). Growth of the Bacterial Cell. Sunderland, MA: Sinauer Associates, Inc.
Jørgensen, B. B., and D’Hondt, S. (2006). A starving majority deep beneath the seafloor. Science 314, 932-934. doi: 10.1126/science.1133796

Jørgensen, B. B., and Marshall, I. P. G. (2016). Slow microbial life in the seabed. Annu. Rev. Mar. Sci. 8, 5.1-5.22. doi: 10.1146/annurev-marine-010814-015535

Kallmeyer, J., Pockalny, R., Adhikari, R. R., Smith, D. C., and D'Hondt, S. (2012). Global distribution of microbial abundance and biomass in subseafloor sediment. Proc. Natl. Acad. Sci. U.S.A. 109, 16213-16216. doi: 10.1073/pnas.1203849109

Kallmeyer, J., Smith, D. C., Spivack, A. J., and D’Hondt, S. (2008). New cell extraction procedure applied to deep subsurface sediments. Limnol. Oceanogr. Methods 6, 236-245. doi: 10.4319/lom.2008.6.236

Kieft, T. L., Wilch, E., O'Connor, K., Ringelberg, D. B., and White, D. C. (1997). Survival and phospholipid fatty acid profiles of surface and subsurface bacteria in natural sediment microcosms. Appl. Environ. Microbiol. 63, 1531-1542.

Klar, T. A., Jakobs, S., Dyba, M., Egner, A., and Hell, S. W. (2000). Fluorescence microscopy with diffraction resolution barrier broken by stimulated emission. Proc. Natl. Acad. Sci. U.S.A. 97, 8206-8210. doi: 10.1073/pnas.97.15.8206

Kogure, K., and Koike, I. (1987). Particle counter determination of bacterial biomass in seawater. Appl. Environ. Microb. 53, 274-277.

Kroer, N. (1994). Relationships between biovolume and carbon and nitrogen content of bacterioplankton. FEMS Microbiol. Ecol. 13, 217-224. doi: 10.1111/j.1574-6941.1994.tb00068.x

Langerhuus, A. T., Røy, H., Lever, M. A., Morono, Y., Inagaki, F., Jørgensen, B. B., et al. (2012). Endospore abundance and D:L-amino acid modeling of bacterial turnover in holocene marine sediment (Aarhus Bay). Geochim. Cosmochim. Acta 99, 87-99. doi: 10.1016/j.gca.2012.09.023

Lee, S., and Fuhrman, J. A. (1987). Relationships between biovolume and biomass of naturally derived marine bacterioplankton. Appl. Environ. Microbiol. 53, 1298-1303.

Lever, M. A., Rogers, K. L., Lloyd, K. G., Overmann, J., Schink, B., Thauer, R. K., et al. (2015). Life under extreme energy limitation: a synthesis of laboratoryand field-based investigations. FEMS Microbial. Rev. 39, 688-728. doi: 10.1093/ femsre/fuv020

Lindroth, P., and Mopper, K. (1979). High-performance liquid-chromatographic determination of subpicomole amounts of amino-acids by precolumn fluorescence derivatization with ortho-phthaldialdehyde. Anal. Chem. 51, $1667-1674$.

Lipp, J. S., Morono, Y., Inagaki, F., and Hinrichs, K.-U. (2008). Significant contribution of archaea to extant biomass in marine subsurface sediments. Nature 454, 991-994. doi: 10.1038/nature07174

Loferer-Krößbacher, M., Klima, J., and Psenner, R. (1998). Determination of bacterial cell dry mass by transmission electron microscopy and densitometric image analysis. Appl. Environ. Microbiol. 64, 688-694.

Lomstein, B. A., Langerhuus, A. T., D’Hondt, S., Jørgensen, B. B., and Spivack, A. J. (2012). Endospore abundance, microbial growth and necromass turnover in deep sub-seafloor sediment. Nature 484, 101-104. doi: 10.1038/nature 10905

Malfatti, F., Samo, T. J., and Azam, F. (2010). High-resolution imaging of pelagic bacteria by atomic force microscopy and implications for carbon cycling. ISME J. 4, 427-439. doi: 10.1038/ismej.2009.116

Montesinos, E., Esteve, I., and Guerrero, R. (1983). Comparison between direct methods for determination of microbial cell volume: electron microscopy and electronic particle sizing. Appl. Environ. Microbiol. 45, 1651-1658.

Morono, Y., Terada, T., Kallmeyer, J., and Inagaki, F. (2013). An improved cell separation technique for marine subsurface sediments: applications for highthroughput analysis using flow cytometry and cell sorting. Environ. Microbiol. 15, 2841-2849. doi: 10.1111/1462-2920.12153

Nagata, T., and Watanabe, Y. (1990). Carbon- and nitrogen-to-volume ratios of bacterioplankton grown under different nutritional conditions. Appl. Environ. Microbiol. 56, 1303-1309.

Norland, S., Heldal, M., and Tumyr, O. (1987). On the relation between dry matter and volume of bacteria. Microb. Ecol. 13, 95-101. doi: 10.1007/BF02011246

Novitsky, J. A., and Morita, R. Y. (1976). Morphological characterization of small cells resulting from nutrient starvation of a psychrophilic marine vibrio. Appl. Environ. Microbiol. 32, 617-622.

Oliver, J. D. (1993). "Formation of viable but nonculturable cells" in Starvation in Bacteria, ed S. Kjelleberg (New York, NY: Plenum Press), $239-272$. 
Parkes, R. J., Cragg, B. A., Bale, S. J., Getliff, J. M., Goodman, K., Rochelle, P. A., et al. (1994). Deep bacterial biosphere in Pacific Ocean sediments. Nature 371, 410-413. doi: 10.1038/371410a0

Parkes, R. J., Cragg, B. A., Fry, J. C., Herbert, R. A., Wimpenny, J. W. T., Allen, J. A., et al. (1990). Bacterial biomass and activity in deep sediment layers from the peru margin [and discussion]. Phil. Trans. R. Soc. Lond. A 331, 139-153. doi: 10.1098/rsta.1990.0061

Parry, B. R., Surovtsev, I. V., Cabeen, M. T., O’Hern, C. S., Dufresne, E. R., and Jacobs-Wagner, C. (2014). The bacterial cytoplasm has glass-like properties and is fluidized by metabolic activity. Cell 156, 183-194. doi: 10.1016/j.cell. 2013.11.028

Pelegri, S. P., Dolan, J., and Rassoulzadegan, F. (1999). Use of High Temperature Catalytic Oxidation (HTCO) to measure carbon content of microorganisms. Aquat. Microb. Ecol. 16, 273-280. doi: 10.3354/ame016273

Romanova, N. D., and Sazhin, A. F. (2010). Relationships between the cell volume and the carbon content of bacteria. Mar. Biol. 50, 556-565. doi: 10.1134/ s0001437010040089

Røy, H., Kallmeyer, J., Adhikari, R. R., Pockalny, R., Jørgensen, B. B., and D'Hondt, S. (2012). Aerobic microbial respiration in 86-millionyear-old deep-sea red clay. Science 336, 922-925. doi: 10.1126/science.12 19424

Schippers, A., Neretin, L. N., Kallmeyer, J., Ferdelman, T. G., Cragg, B. A., Parkes, R. J., et al. (2005). Prokaryotic cells of the deep sub-seafloor biosphere identified as living bacteria. Nature 433, 861-864. doi: 10.1038/nature 03302

Schumann, R., and Rentsch, D. (1998). Staining particulate organic matter with DTAF - a fluorescence dye for carbohydrates and protein: a new approach and application of a 2D image analysis system. Mar. Ecol. Prog. Ser. 163, 77-88. doi: $10.3354 /$ meps 163077
Simon, M., and Azam, F. (1989). Protein content and protein synthesis rates of planktonic marine bacteria. Mar. Ecol. Prog. Ser. 51, 201-213. doi: 10.3354/ meps051201

Starnawski, P. (2016). Diversity, Persistence and Evolution in Marine Sediments. Ph.D. thesis, Center for Geomicrobiology, Aarhus University.

Troussellier, M., Bouvy, M., Courties, C., and Dupuy, C. (1997). Variation of carbon content among bacterial species under starvation condition. Aquat. Microb. Ecol. 13, 113-119. doi: 10.3354/ame013113

Trueba, F. J., and Woldringh, C. L. (1980). Changes in cell diameter during the division cycle of Escherichia coli. J. Bacteriol. 142, 869-878.

Vrede, K., Heldal, M., Norland, S., and Bratbak, G. (2002). Elemental composition (C, N, P) and cell volume of exponentially growing and nutrient-limited bacterioplankton. Appl. Environ. Microbiol. 68, 2965-2971. doi: 10.1128/AEM.68.6.2965-2971.2002

Whitman, W. B., Coleman, D. C., and Wiebe, W. J. (1998). Prokaryotes: the unseen majority. Proc. Natl. Acad. Sci. U.S.A. 95, 6578-6583. doi: 10.1073/pnas.95. 12.6578

Conflict of Interest Statement: The authors declare that the research was conducted in the absence of any commercial or financial relationships that could be construed as a potential conflict of interest.

Copyright (c) 2016 Braun, Morono, Littmann, Kuypers, Aslan, Dong, Jørgensen and Lomstein. This is an open-access article distributed under the terms of the Creative Commons Attribution License (CC BY). The use, distribution or reproduction in other forums is permitted, provided the original author(s) or licensor are credited and that the original publication in this journal is cited, in accordance with accepted academic practice. No use, distribution or reproduction is permitted which does not comply with these terms. 